\title{
Teachings of Patience and Sincereness in the Oral Tradition of Childhood Nolam in Talang Maur, Lima Puluh Kota District, West Sumatra
}

\author{
Daratullaila Nasri ${ }^{1, *}$ Mulyadi Mulyadi² \\ ${ }^{1}$ Balai Bahasa Provinsi Sumatera Barat, Indonesia \\ ${ }^{2}$ Balai Bahasa Provinsi Sumatera Barat, Indonesia \\ *Corresponding Author,Email:daratullailanasri@gmail.com
}

\begin{abstract}
The article entitled "Teachings of Patience and Sincerity in the Oral Tradition of Childhood Nolam (Nolam Kanak) in Talang Maur Lima Puluh Kota District, West Sumatra discusses the nature of the Nolam Kanak tradition. Adhering to the concept of tradition initiated by Vansina, the tradition needs to be inherited so that the values contained in it can be applied in life. To find out these values, this research used descriptive analysis method. From this method, the researchers found that the nature of the Nolam Kanak-Kanak oral tradition instills the teachings of patience and sincerity as well as a motivation for people to live life. The teachings were delivered in a very beautiful language, namely in the form of poetry. Then, it is spoken with a very distinctive rhythm. Therefore, children's nolam texts can be called an art. The most important thing about the Nolam Kanak-Kanak tradition is that there is no misunderstanding in the community's understanding of the concept of child death at an early age.
\end{abstract}

Keywords: Childhood Nolam, Oral Tradition, Patience, Sincerity.

\section{INTRODUCTION}

Vansina stated that tradition is an (unwritten) message [1]. Referring to the Big Indonesian Dictionary, the word message means 'orders, advice, requests, mandates conveyed through other people' [2]. Vansina further explained that maintaining the message is a task from generation to generation [1]. Related to this tradition, in the region of Nagari Talang Maur, Lima Puluh Kota Regency, West Sumatra, there is one tradition whose condition is assumed to be almost extinct, namely the oral tradition of nolam (nalam) [3][4]. The location where the tradition lives is quite far from both the city government center and the district capital, which is about $25 \mathrm{~km}$ or takes about 45 minutes of travel.

The term nolam is used by the people of Talang Maur. However, in other places, such as in Mungka, which is still next door to Talang Maur, they call this tradition hikayat. Meanwhile, in Pariaman, Agam, and Pesisir Selatan, it is called nazam [5] and some also use the term nalam. In connection with the difference in terms, the article with the title "Nazam: Pakiah Geleng Islamic Art" written by Yusriwal [6] explains this very well. Yusriwal traced the terms nalam and nazam from several dictionaries that existed at that time.

In the Minangkabau-Melajoe-Riau Language Dictionary [7] by M. Thaib St. Pamoentjak found the word nalam, but did not find the word nazam. According to him, nalam can be equated with nazam which means 'telling stories with lagoe, especially about religion or which contains teachings. The General Indonesian Dictionary (Poerwadarminta, 1984) collects the words nalam and nazam. "Nalam" means composition of poetry (poems); "reveal": rhyme (poetry); telling stories with songs; "spoken": rhyme; tell with song; compose. "Nazam": as rhyme (poem); essay; "to sharpen": to rhyme; fabricate; compose; night. Then, in the Big Indonesian Dictionary starting from the first edition to the last or fifth edition in 2018--contained the words "nalam" and "nazam". "Nalam": composition of poetry (poems, essays); "live": reading poetry or telling stories with songs; rhyme (poetry); "to rehearse": to narrate with a song; compose; rime. "Nazam": a poem of Persian origin, consisting of two lines, rhyming two-two or four-four, it is about a loyal and virtuous court servant.

In addition, Yusriwal [6] also refers to several research results that have conducted studies on nalam 
and nazam. From the results of the study, it can be seen that there is no agreement on the use of any of the terms, either nalam or nazam. This is exemplified by Yusriwal: Agus Deaman (1984) uses the term "nadzam", Dada Meuraxa (1974) "najam", Wan Mohd. Shaghir Abdullah (1993) "nazham", Emral Djamal (1999) "nizam. However, Yusriwal stated that researchers used the word nazam more, for example Labai Sidi Rajo (1899), Tuan Haji Ahmad bin Haji Abdul Rauf and Tuan Haji Omar bin Haji Othman before 1928, Harun Mat Piah (1989), Baharudin Ahmad (1992), Umar Junus (1997).

In the context of this paper, what is meant by nolam or nalam is a sung poem, which contains good teachings, such as an understanding of the levels of good and bad, heaven and hell, and news of death (interview with Datuk Bijo, 2021).

As Vansina stated above that tradition is a message. Likewise, with this nolam which is one of the traditions owned by the Talang Maur community which of course has a message that needs to be passed down from generation to generation. However, the condition of the nolam's life force is threatened so that the message that should have been passed on from generation to generation has now simply stopped.

The condition of the nolam oral tradition was discovered after conducting a literature mapping study in Lima Puluh Kota Regency in March 2021. From interviews conducted with traditional speakers, community leaders, and community owners of the tradition, it was found that only two speakers of the nolam oral tradition were over the age of 65 years. The speaker never again appeared to say nolam. The speaker's lack of performance has something to do with the community that owns the tradition. In this case, it is illustrated that the community also feels that they no longer have any interest in their traditions. If studied further, of course, there are many factors that cause the nolam tradition to be threatened with extinction.

However, the focus of this paper does not lead to that. This article will discuss the "message" contained in the oral tradition of nolam. This is done in an effort to save the contents or contents. If the saving of tradition itself cannot be done, it does not mean that its essence or essence cannot be saved. It can be analogous to a manuscript that is almost destroyed, but in certain parts there is still something that can be known about the text. As observers or researchers, we may not be able to save the manuscript, but we can still save its contents.

Therefore, this article intends to discuss the teachings of patience and sincerity contained in the nolam text. There are several types of nolam according to the title, namely "Childhood Nolam", "Prophet Shaving Nolam", "Prophet Barompeh Nolam", "Burial Torment Nolam", "Death Pain Nolam",
"Khabar Mahsyar Nolam", and others. All types of nolam are sung in every wirid (a religion teaching) recitation activity, religious commemoration, and circumcision of the apostle. Especially for the death of a child, it is prioritized to convey "Nolam KanakKanak". In this case, the researcher specifically discusses "Nolam Kanak-Kanak".

According to Yunus [5] in his research entitled "Literary Protest against Religious Understanding: Childhood Nazam Studies" (2001) states that the text of nolam (or Yunus using the term nazam) is the work of Karimullah bin Ummi Labai Sidi Rajo from the Sungai Pua. From Yunus' book, information was obtained that Karimullah bin Ummi Labai Sidi Rajo composed many Islamic literary works such as nazam poetry, poetry containing religious teachings. In addition to "Nazam Kanak", his works are "Nazam Dangers of the Hereafter", "Prophet Shaving", and the poem "The Padang Panjang Earthquake". Besides being known as a poet at the time, Karimullah bin Ummi Labai Sidi Rajo was also a writer of story and history books. Based on Yunus's statement, "Nazam Kanak-Kanak" has been published 18 times in the Arabic-Malay (Arabic Pegon) edition by HMS Sulaiman and even continues to this day in the Latin edition.

Related to this article, the source of research data was "Nolam Kanak-Kanak" in the Minangkabau language with the Talang Maur language style. When compared with the Indonesian version of "Nazam Kanak-Kanak" in Yunus' book, "Nolam KanakKanak" is no different because the Minangkabau version is only a translation from Indonesian. Even though it has been written down, nolam is still delivered orally by the speakers.

As a literature review, the research which is directly related to Nolam Kanak is the research that was conducted by Yunus. In addition to using the printed nazam text, Yunus also took field data in three places, namely Pariaman, Agam, and Pesisir Selatan. In his research, Yunus saw the myth that the death of a child in the nazam poem circulated in the community that supported it. The death of a child is considered to have a function that does not exist in the view of Islam. One of them is that a child who dies in his childhood will become a resident of heaven who will benefit his parents in the hereafter to be guaranteed as a resident of heaven as well. This assumption also means that the death of children in this world is a sadness, but also a blessing for parents in the hereafter, assuming that the child is the legitimacy of his parents to enter heaven. With his research, Yunus wants to investigate whether the "Nazam Kanak-Kanak" will have an influence on the development of trust that develops in three regions, namely Pariaman, Pesisir Selatan, and Lima Puluh Kota. In addition, he also revealed the extent to which 
the content of the nazam supports the myth or the extent of the influence of the nazam literature [5].

In addition, the nazam research conducted by Putra [8] with the title "Theocentric Humanism in Minangkabau Islamic Literature: A Study of Minangkabau Nazams. With the theocentric humanist concept, the researcher concludes that nazam has teaching and coaching values related to Islamic teachings.

In terms of the object of this research, it has similarities with the research conducted by Yunus, namely using the Nolam Kanak-Kanak text. However, what distinguishes this research is the context of the text. The context of the text here is the place where the tradition lives and develops. In this case, the nolam tradition lives in the Talang Maur community.

\section{METHODS}

Nolam is a form of oral literature. Oral literature research requires a unique method [9]. By formulating the opinion of Alan Dundes, Endraswara revealed three stages of oral literature research methods, namely 1) collection, 2) classification, and 3) analysis. This research also refers to the three concepts.

The three methods are carried out using the following technique. First, the author conducted a field survey. Second, oral and written data collection. Oral data was collected by conducting interviews with Nolam Kanak speakers, community leaders, ulama, and community owners of traditions. The oral data collection technique was carried out by recording (audio or audio-visual), recording, shooting, and observing. Collecting written data by photographing Nolam Kanak found in the field and then retyping it. Fourth, data classification, and fifth, data analysis.

Data analysis was carried out using a descriptive method, namely the data collected was compiled, analyzed, and interpreted [10].

\section{RESULTS}

\subsection{Nolam as Art}

Minangkabau people used to know the tradition of maratok or wailing. The tradition has a different name in each region. One example is in the Lima Puluh Kota area, specifically in Bukik Limbuku, which is known for the ratok Bawak tradition. Ratok Bawak is a tradition of mourning corpses [11]. The tradition of ratok Bawak lives in a limited environment, namely in the family of the Payobada Tribe, especially the descendants of the nephew of Penghulu Basa Nan Koruk's son who died. The tradition is generally carried out when a male relative dies. All the oversized objects belonging to these people are removed during the ratok Bawak procession. People who are left behind, like, the corpse's mother will lament the good that her child has done. In her lament, the mother also tried to persuade her daughter-in-law to accept the death patiently and sincerely. The corpse's wife also mourned her husband who had left. If the husband who has died has more than one wife, then the wives are like competing in mourning for their husbands. they tell all the behavior of her husband during life.

At that time the tradition of ratok Bawak really lived in the community. The ratok Bawak procession is a spectacle by the surrounding community. The family also facilitates the tradition, namely presenting or inviting ratok craftsmen who really have the expertise to mourn. The tradition of inviting ratok artisans (a singer in the traditional art that is practiced) because the family is not good at mourning the corpse with a sad and heart-wrenching song. The ratok's lament will trigger the family to cry even more and even beat their bodies and roll over in front of the corpses.

The tradition of ratok Bawak in the end did not continue because there was a prohibition on displaying it by ninik mamak and penghulu. The ban was also issued by the family of the Penghulu Basa nan Koruk as the owner of the tradition.

The prohibition came out along with the increasing public understanding of Islamic teachings. In Islam, it is not permissible for a person to lament and even torture himself at the time of death. In the hadith there is a threat in the form of a special punishment in the hereafter for people who like to mourn over corpses. It was narrated from Abu Malik Al-Ash'ari radhiyallahu 'anhu, the Prophet sallallaahu 'alaihi wa sallam said,

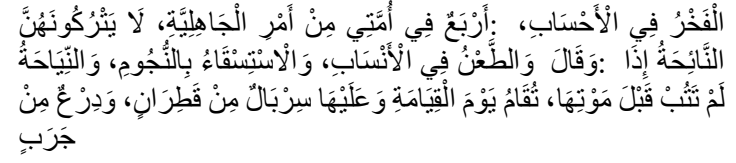

"There are four special things of ignorance that are still attached to my ummah and they have not left it: (1) boasting of the merits (strengths or greatness) of their ancestors; (2) denounce nasab (lineage); (3) attribute the rain to certain stars; and (4) and niyah (wailing for the dead)."

In another hadith it is stated that the Prophet sallallaahu 'alaihi wa sallam separated himself from his people who mourned the dead. It was narrated from the companion of 'Abdullah bin Mas'ud radhiyallahu 'anhu, the Prophet sallallaahu 'alaihi wa sallam said,

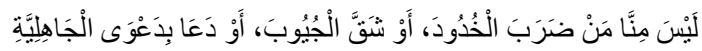

"It is not from our group who slaps the cheek, tore the collar of the shirt, and calls out with the call of 
jahiliyyah (wailing)." (Narrated by Bukhari no. 1294 and Muslim no. 103) [10].

The majority of Minangkabau people are followers of Islam, who are famous for their traditional philosophy of life, based on the syarak (the law of Islam), and the syarak with the book of Allah. Thus, all behavior and actions must refer to the book of Allah and the hadith of the prophet that was revealed to the messenger of Allah.

Traditions that are not in accordance with religious teachings began to be abandoned. They turned to the tradition introduced by the surau people, namely Nolam Kanak-Kanak. As explained by Datuk Bijo (interview) that the Nolam Kanak-Kanak tradition developed because people were not allowed to mourn the dead bodies.

The Nolam Kanak tradition is present in the community in the form of art. Nolam Kanak-Kanak is declared an art because the text in the form of poetry is sung to convey it. Nolam Kanak-Kanak poetry is sung by the nolam craftsman with a distinctive rhythm. The very solemn rhythm of the nolam craftsman is enough as a heart healer for the family who is grieving because of the death of their child. Sadness over the departure of their child who became their baby is not that easy to get rid of. However, the content or content contained in the nolam text is enough to make them think, absorb, and reflect on the test that befell them.

The presence of Tukang Nolam in the homes of families who died in childhood were invited and some even came of their own volition. There are male and female nolam artisans. They came with the aim of comforting the family so as not to drag on in sadness. Usually this event is held on the second night after the death of the child and can continue on the following night according to the wishes of the family. The reading of Nolam Kanak-Kanak's poetry begins after the tahlilan or yasinan program, around 21.00-22.00. The implementation time is also not fixed, sometimes adjusting to the needs of the family.

The nolam artisan at the event was also treated to food and drinks. The dish is not a must, but as a sign of the host's gratitude to his guests.

\subsection{Children Nolam as Text}

The Nolam Kanak-Kanak texts found in Talang Maur consist of several titles, namely 1) "Khabar Kanak-Kanak di Sarugo"; 2) "Kanak-Kanak Kalua di Sarugo"; 3) "Kanak-anak Batamu dengan Ayah Bundo"; 4) "Baimbang Doso jo Pahalo"; and 5) "Kanak-Kanak Mancari Ayah jo Bundo". The following is an explanation of Nolam Anak and what is contained in the text.

\section{Khabar Kanak-Kanak dalam Sarugo (Children's News in Heaven)}

Tolan sahabat donga curito Iyolah sungai dalam sarugo Dari pado dadiah putiah aianyo

Minuman kanak-kanak nan mudo-mudo

Dalam sarugo pokannyo rami Tatapi bukan tompat jua bali Pokan kanak-kanak barami-rami Tompat bamain basuko hati

Dalam sarugo kayunyo godang Rantiang dan dahan bacabang-cabang Buahnyo lobek bukan kupalang Rasonyo manih sampai katulang

Daunnyo rimbun tidak takiro Satiok rantiang lobek buahnyo Rasonyo sojuak sangat manihnyo Itu makanan dalam sarugo

Sangatlah sojuak itu makanan Kanak-kanak rusuah gaduah pun bukan Mandonga ayah bolahan badan

Saroto bundapun semikian

Rusuahnyo itu talalu sangat Sampai badiri hari kiamat Ayah dan bundo batapo sipat Maso di dunia kok kurang ibadat

Rusuahnyo hati bukan kapalang Sadikit tidak bahati sonang Hari kiamat jikalau datang Ayah dan bundo batapo sayang

Babitu halnyo satiok hari Di bawah kayu banama Tubi Mangona ayah balahan hati Sarato bundo damikian lagi

Jikalau datang angin sarugo Kayu Tubi itu nyoriang bunyinyo Singguang-basingguang daunnyo Lobiah bak buni biola Cino

Di bawah kayu data sakali Kasiaknyo omeh intan dan podi Tompat kanak-kanak barami-rami Bamain-main basuko hati

Kanak-kanak bamain ka sana si nan Di bawah kayu rimbun daunnyo demikian Itu karajo sapanjang zaman Mananti kiamat tuhan datangkan 
Hari kiamat jikalau tibo

Kapado Jibril turun suaro

Wahai Jibril dongakan kato

Kaluakan kanak-kanak sakarang nangko

Hondak kaluakan sakarang kini Di bawah kayu banamo Tubi

Poi manyonsong ayah dan Umi

Kapadang kiamat buliahnyo nanti

Mandonga kato demikian bunyinyo

Jibril bajalan dengan sugiro

Lamo sasaat sampailah tibo

Di bawah kayu Tubi namonyo

$\cdots$

\section{Translation}

Tolan friends hear the story

It's a river in heaven

From the white curd of the water

Young Children's Drinks

In the paradise of hemp week

But not a place to buy and sell

Children's week is bustling

Playground for joy

In heaven the wood is big

Branches and branches

The fruit is absurdly dense

It's sweet to the bone

The leaves are lush beyond measure

Every branch is full of fruit

It's cold, it's so sweet

It's food in heaven

It's very cool food

Even the kids are noisy, aren't they

Listening to dad parting

And so is the mother

The chaos is too much

Until doomsday stands

Father and mother how nature

The time in the world is less worship

The chaos of the heart is absurd

a little displeased

Doomsday if it comes

Mom and dad how dear

That's how it is every day

Under the wood called Tubi

Remembering father mate

And the mother is like that again
If the wind of heaven comes

Tubi wood is loud

Alluded to dannya

More like Sina's violin

Under the flat wood

The sand is gold and diamonds

Crowded nursery

Play happy

Children play here and there

Under the leafy wood

It works all the time

Waiting for the apocalypse God will come

Doomsday if it comes

To Jibril the voice goes down

O Jibril listen to the words

Get the kids out right now

Take it out now

Under the Wood named Tubi

Go meet dad and Umi

Can he go to the field of doomsday later

Hearing the word like that sounds

Jibril walked quickly

It took a while to arrive

Under the Tubi wood his name is

$\cdots$

In this section the text explicitly describes the state of childhood in heaven and also describes the beauty and pleasures of heaven. The atmosphere of heaven is described as a river whose water is made of milk for the children to drink, there is a market where they gather and play with joy, there is a tree whose fruit is very sweet to enjoy. However, all the pleasures were not complete for them because they had not been able to mingle with their father and mother. The children still feel lonely until the apocalypse comes. When the apocalypse came, the children were expelled from heaven and gathered under the Tubi tree by Jibril on the orders of Allah. They will all be taken to the apocalypse to await the arrival of their father and mother. At that time the children wore very luxurious clothes and diamond jewelry, both boys and girls. At that time, in his left hand he held an umbrella to protect him from the heat and in his right he held a jug filled with water to give to his father and mother when they met.

Kanak-Kanak Kalua dalam Sarugo (Children come out in Heaven)

Takadia Allah Tuhan nan kayo

Kanak-kanak bajalan pulo basamo-samo 
Jikalau godang samo godangnyo Laki-laki perempuan ado bedonyo

Bajalan baiak bukan kupalang Batolan-tolan basamo-samo godang Cahayonyo payuang celang gumelang Tangkainyo perak intan bakarang

Daunnyo ameh indah bacayo Ditimpo paneh bamego-mego Tirai di topi yakup parmato Karunia Allah Tuhan samato

Lamo bajalan ado sasaat Tibolah pulo di padang kiamat Payuang dikombang dek sangat angek Sojuak rasonyo tubuah pun sonang

Kanak-kanak bajalan sampailah tibo Di tongah padang kiamat namonyo Batomulah jalan basimpang duo Kanak-kanak baronti pulo di sano

Simpang jalan sudahlah torang jalan sarugo kampuang yang monang Basimpang lagi pulo di bilang Ayah jo bundo di mano goran

Hati nan rusuah bacampua riang Ayah jo bundo rasokan datang Togak di situ bahati mamang Di tongah jalan basimpang duo

Aia mato bacucua kiri dan kanan Duduak bamonuang baibo hati Kanak-kanak duduak barami-rami Ayah jo bundo di mano kini

Di mano ayah bundo sakarang Lah putiah mato dek mamandang Di tongah jalan duo basimpang Ayah jo bundo bolun datang

Kanak-kanak manyoru pulo di sanan Togak badiri di simpang jalan Wahai Allah Tuhan Rahman Ayah jo bundo di mano gorang ....

\section{Translation}

God's destiny is rich Children walk together If it's big, it's the same size Men and women are the same

Going amazingly well
Hang out together the drums

The light of the umbrella is shining

The stem is silver, diamond is rocky

The leaves are golden, beautiful and dangerous Overwhelmed by the heat of bamega-mega The curtain on the edge of the gem Jacob God's gift alone

Long walk there is a moment Arrived in the Field of Judgment The umbrella on the deck is very warm It feels cool and the body is delicious

Children walk until they arrive

In the middle of the field of doomsday his name

Meet the two-way cross

The kids stop there too

The crossroads are clear

The winning village heaven road

It's said to be crossing again

Where's mom and dad

A chaotic heart mixed with joy

Mom and dad feel dating

Stand up there, be careful

In the middle of the crossroads

Tears flowing right and left

Sitting contemplating barhiba heart

Children sit together

Where are mom and dad now

Where are mom and dad now

My eyes are white from looking at

In the middle of the road two intersect

Mom and Dad haven't come yet

The children are also calling there

Standing tall at the crossroads

O Allah, Lord Tahman

Where are mom and dad

$\cdots$

In the second text, it is told that children are flocking to the apocalypse. On their way they met a two-way intersection, at that intersection they waited for their father and mother. They hoped that their mother and father would go down that road. They waited a long time but father and mother had not yet come. Everyone who passed in front of them was always asked whether the old man was his father and mother. The parents who were questioned admitted that they were indeed his parents. This is evidenced by the explanation that the child's face is similar to theirs. Then, the father and mother immediately asked for 
water in the child's jug because he was very thirsty. However, children do not immediately believe it. The child also asked the day of birth and death. If the question is answered, the child will give the water that the father and mother asked for. However, the water will not be handed over if the question is not answered. It turned out that the two parents were not the father and mother. Then the child continued to look for and ask every parent who passed in front of him.

\section{Kanak-Kanak Batamu dengan Ayah Bundo (Children Meet with Father and Mother)}

Sukonyo hati bukan kupalang Ayah dan bundo nyatolah torang Sampai batamu tangan dipogang Lalu dicium dipaguk pinggang

Ayah dan Bundo bapalun-palun Dipogang anak lalu dicium Kasiah bacorai batahun-tahun Ayia dikendi lalu diminum

Ayia diminum hilang dahago Sangatlah Sojuak lomak rasonyo Kapado anak lalu bakato

Wahai anakku cahayo mato

Wahai anakku bolahan badan

Salamo bundo anak coraikan

Tidaklah lupo diangan-angan

Jikalau lalok jadi rasian

Tidaklah bundo basonang hati Jikalau lalok manjadi mimpi Bak raso iduik anak nan mati Mato tabangun hilang sakali

Sadikit tidak bahati sonang Minum tak sojuak makan tak konyang Rasonyo tubuah bak bayang-bayang Kuruih lah badan litak lah tulang

Wahai anakku bolahan badan Di mano dapek iko pakaian Goang dan subang parmato intan Podi mutiara Yakup Marojan

Di mano dapek golang dan subang Bapayuang omeh baturang-turang Tangkainyo perak intan bakarang Kapado bundo borilah torang

Kanak-kanak itu bakato
Wahai lah ayah sarato bundo Parosaian bundo sudahlah nyato Parosaian ambo dongakan pulo

Parosaian ambo hondak dongakan Salamo ambo bundo coraikan Sungguah banyak parosaian Bukan kupalang susah pikiran

\section{Translation}

The joy of the heart is absurd Mom and Dad, it's clear Until we meet hands held Then kissed on the waist

Mom and dad are swinging Holding the child and then kissing Love divorced for years Water in a jug and then drink

Drink water to get rid of thirst It's so cool it tastes good To the child then said

O my son the light of the eye

O my son cleavage

As long as the child's mother divorces Don't forget to dream If you sleep so rasian

No mother is having fun If sleep becomes a dream Like the taste of life anan who died Eyes wake up lost once

A little displeased Drinking is not cold, eating is not full The body feels like a shadow Skinny body tired bones

O my son cleavage

Where can I get this clothes

Diamond bracelet and earring Budi pearl Jacob Marjan

Where do you get bracelets and earrings? Under the golden umbrella The stem is silver, diamond is rocky To mother, give light

The boy said

$\mathrm{O}$ father and mother Mother's feelings are real Listen to my feelings too 
The feeling I want to hear

As long as I am divorced

So many feelings

It's absurdly hard to think

In the third part, it is an episode of the child meeting his father and mother. They hugged and missed each other because they had not seen each other for years. Father and mother drink water in a jug that their child always carries. At that time they told each other what they had experienced when the separation occurred. Father and Mother told how sad they were when their child died. The sadness made him unable to eat so that his body became thin. Similarly, the child narrates that death is painful for him. He had to be separated from his father and mother as a place to depend. The sadness is even more painful when the people he left behind mourn his departure. The pain felt like a hammer raining down on his body. Destroyed and melted all limbs when loved ones mourn his departure. As a cure for the child's sadness, the angels came to comfort him and gave him fine clothes and luxurious jewelry. However, all of that has not been able to cure a child's longing for his father and mother. Happiness comes when they are together.

\section{Batimbang Doso jo Pahalo (Weighing Sin and Rewards)}

Rundiang sudah habih bincangan

Daripado Allah turun pidoman

Wahai Jibril hondak dongakan

Sakalian umat hondak halaukan

Halaukan umat pulo samonyo

Ka tongah padang kiamat namonyo

Janganlah tingga surangpun juo

Buliah ditimbang doso jo pahalo

Mandonga pidoman daripado Allah

Kanak-kanak itu sangatlah susah

Mamikiakan bundo sarato ayah

Kok borek doso ka narako hawiyah

Jibril sugiro pulo mahalaukan

Surangpun tiado nan tingga

Babagai Langkah umat di sanan

Satongah poruk inyo kosongkan

Babagai rupo umat malangkah

Sotongah pulo kakinyo guyah

Togak bapincang antaro cokah

Kapalo baantuak jadilah pocah
Padang mashyar sangatlah susah Kamano diimbau ibu dan ayah Badan nan robah umat mamijak Bak buni aruwah darunnyo tapak

Allahurobbi lowehnyo padang Tidaklah tontu bujua malintangnyo Sojuk rasonyo mato mamandang Manusia bajalan tatungkuk tatilantang

Laamo bajalan di padang pato Di padang maukuf baronti pulo Mananti hukum supayo tapinto Bayiak dan buruak di sanan nyato

Bayiak dan jaek nyato di sanan Barang siapo buruak bagian Hitam mukonyo bak rubah-rubah topian

Tontu narako tompat kadiaman

Tontu di situ bayiak dan jaek

Karano baru sudah diliek

Roman barubah mukonyo pucek

Dalam narako tatulih tompek

…

\section{Translation}

Negotiation is over

Than Allah descends the guidelines

O Jibril want to hear

All the people want to get rid of it

Get rid of all the people

In the middle of the field of doomsday his name

Don't leave anyone either

Can sin and reward be weighed?

Hear guidance from Allah)

Children are so hard

Thinking of mom and dad

If the $\sin$ is heavy, go to hell hawiyah

Jibril immediately dispelled

No one is left

The various steps of the people there

Half empty stomach

Various kinds of people walk

Half of his legs are wobbly

Upright limping between cokah

Heads fall apart

Padang masher is very difficult Where are you asking mom and dad 
The body that fell, people stepped on

Like the sound of a tread's spirit

Alluhurobbi, the field is clear

Not necessarily transverse

It's cool to see the eye

Human walking face down

Long walk in the data field

In the field of Maukuf Baronti too

Waiting for the law to be prosecuted

The good and the bad there are real

Good and evil are real there

Whoever is bad part

His face is black like a fox's edge

Of course hell is a place to live

Of course there is good and evil

Because it's just seen

Roman turns pale face

In hell is written place

In this section Allah ordered Jibril to gather mankind in the field of Judgment. At that time all human beings will be weighed all the good and bad deeds. Listening to this, the chi ldren are worried about the fate of their father and mother. If the father and mother have worse than good, then Hawiyah Hell is the place. Jibril immediately did his duty to herd all mankind. At that time, all human states were shown. There are people who limp their way, there are people who beat their heads until they break. Some were trampled by other people because so many people at that time were all busy determining their own destiny. Some shouted and roared because the scales of ugliness were more. When walking on sidratulmuntaha the person immediately fell into hell. There are also those who walk sidratulmuntaha like lightning, that's a human who has a lot of deeds. In the crowd, the children were also busy looking for their father and mother.

\section{Kanak-Kanak Mancari Ayah dan Bundo (Children Looking for Mom and Dad)}

Wahai sahabat tolan saudara

Kito hontikan khabar naroko

Kapado kanak-kanak kumbali kato

Mancari ayah saroto bundo

Kanak-kanak itu lalu bajalan

Ditongah padang batolan-tolan

Payuang dikiri kendi dikanan
Barisi ayia akan minuman

Bajalan pulo kian kamari

Payuang dikombang di jinjiang kendi Dibuang pandang kanan dan kiri

Ayah dan bundo tiado lagi

Ayah dan bundo tiado berjumpa

Sudah batimbang dosa pahalo

Sakarang kini ontah dimano

Ontahlah hanyuk masuak naroko

Kanak-kanak manyoru maso disanan

Wahai ya Allah Tuhan Rohman

Ayah dan bundo dimano goran

Masuak naroko buruak bagian

Kanak-kanak manangih lalu mangaruang Wahailah ayah bundo nan kanduang Maso didunia kami di dukuang

Kini bacorai dek buruak untuang

Ayah dan bundo untuangnyo malang Maso didunia batapo sayang Mangasuah kami tingga sumbayang Kini bacorai sobab dek malang

Maso didunia batapo susah Mangasuah kami sangatlah payah Manyosahkan kain loyo dan muntah Amal sumbayang tidak bapaidah

Wahailah ayah sarato bundo Sayang di anak tidak takiro Amal ibadat tidak mangapo

Kini barondam dalam naroko

Wahailah bundo nan kanduang Sambilan bulan bundo manganduang Sampailah layia kami didukuang Kini lah sansai dek buruak untuang

....

\section{Translation}

O dear friend, brother

Let's stop the news of hell

To the children again the word

Looking for mom and dad

The children then walked In the middle of the field together Umbrella on the left, jug on the right Contains water for drinks 
Walk here and there

Umbrella carried in a jug

Throw away right and left

Mom and Dad are gone

Mom and dad don't meet

Already weighed the sin of the reward

Now it's somewhere

I don't know, I'm going to hell

Children call for time there

O Allah, Lord Rahman

Where are Mom and Dad?

Enter hell bad part

Children cry and then roar

$\mathrm{O}$ real mother and father

Time in our world supported

Now scattered because it's bad luck

Father and mother are fortunately poor

Time in the world how dear

Raising us to pray

Now divorced because of bad luck

How hard is the time in the world

Taking care of us is so hard

Washing sluggish cloth and vomiting

Prayers are useless

O father and mother

Love for children is immeasurable

Worship is okay

Now soaking in hell

O real mother

Nine months pregnant

Come to the end we are supported

Now it's Sansei because it's bad luck …

In this last part, it is told that the children are looking for their father and mother who still have not met when considering the practice. The children kept walking looking for their father and mother, carrying water in a jug in their right hand and an umbrella for shelter in their left hand. Children continue to walk while lamenting the fate of their parents who may have gone to hell because they still haven't been found. In the midst of their desperation, the children begged Allah to allow them to meet their father and mother. If the parents have been in hell, the children are also willing to be put in hell as long as they can gather together with their parents. Allah granted the child's wish by ordering Jibril to remove the two parents of the child. Allah has forgiven the sins of the father and mother of the child. Jibril immediately carried out Allah's orders. Jibril went to hell with the children to pick up her father and mother. Jibril conveyed what the purpose of his arrival was to the angel Malik. Malik opened the door of hell, where the fire was blazing and very hot. Children enter hell and take their father and mother out. As inhabitants of hell, the father and mother of the child have black marks on their foreheads. The black mark disappeared after they bathed in Bukik Araf which is located between heaven and hell. Then the child with his father and mother entered heaven with a very happy feeling.

In essence, Nolam Kanak-Kanak's poetry is sung in the midst of a family that is experiencing grief, none other than to instill patience, sincerity, and motivation to worship Allah. The following will describe the meaning of these three key words, namely patience, sincerity, and motivation.

Nolam poetry as a literary work certainly has a function for the heir community. According to Horace, alluding to the function of literature means to unravel the relationship between humans and literature [13]. In other words, as the following expression goes, "good literature is the second path to truth." In essence, the function of literature is expressed by Horace in very short words, but dense in meaning, namely dulce et utile which can be translated as "entertainment" and "teaching" [13]. Therefore, the function of literature only plays on the two realms of the word.

The same is true of Nolam's poetry. Nolam poetry is spoken in the midst of a family who is experiencing grief on the seventh night and so on if the family still wants to get together to release their grief.

The death of a child is not something that is easily forgotten and will never even be forgotten for the father and mother because God places the child in a very noble position in the life of his parents. According to Kristina [14], among the honors that Allah has bestowed on their parents are 1) children are a trustee, as can be seen in the Al-Quran Surah Az Zariyat verse 56 [15]. Amanah literally means 'something entrusted to someone else'. Based on this, it means that parents who have children are creatures who are trusted by God to entrust the creatures he created. As a parent, you must take care of the trust that was entrusted to you. 2) children are a gift from Allah. The presence of children can bring happiness to their parents [15]. 3) children as a test and a trial for their parents (At Taghabun verse 15) [15]. 4) Children as the successor of the lineage (Al Baqarah verse 133) [15]. The presence of children is the successor of offspring and the ideals or dreams of their parents. Therefore, parents have an obligation to educate their children on the path of goodness. 5) Children as guardians of parental rewards. In this context what is meant is a pious child. Children who have obedience and piety only to Allah. His piety guarantees that his prayers for 
his parents will be answered. 6) Children as independent beings, namely children have their own destiny. All attitudes and actions taken by children are their accountability to Allah [14].

However, when the death of a child comes in the lives of parents, they must be sincere and patient to accept it. In this context, nolam poetry plays a role in providing entertainment and teaching to the community. Tukang Nolam who also has good religious knowledge and insight conveys and explains the wisdom behind the child's death. At that moment the family instilled an attitude of patience, sincerity and at the same time the motivation to increase piety to Allah.

Patience according to language means "preventing" and "holding back", while according to syarak is "restraining the lust from the will and holding back the tongue from complaining, and holding the limbs from hitting the cheeks, tearing clothes because of sadness and so on [16]. Patience is peace of mind in the face of trials. Sincerity means fulfilling Allah's commands without considering any personal gain or reward [16]. Finally, the word 'motivation' is an impulse that arises in a person consciously or unconsciously to take an action with a specific purpose [2].

Talking about patience and sincerity are words that are easy to say, but hard to practice. When someone is afflicted with disaster and we as visitors will say hopefully you are patient and sincere in accepting this test. However, when calamity befalls us, it is so hard for us to be patient and willing to accept this fact. However, as religious people we are obliged to have and practice patience and sincerity in ourselves so that all the tests and trials we face can be accepted with grace.

The teachings of patience and sincerity are instilled through the nolam text. Explicitly in the text is described the condition of all humans in the afterlife for all the deeds they have done while in the world. The final destination of the afterlife is said in the text only two, namely heaven and hell. If you don't want to feel the torments of hell, then as a human being, you are submissive and obedient and patient and sincere for something that has been determined by Allah. Don't complain about the destiny that Allah has given, then Allah will put the people into paradise.

All the descriptions of human life that have been described in the text of Nolam Kanak-Kanak above are enough to teach listeners to motivate themselves to do their best in life so that they do not become losers.

\section{CHILDREN'S NOLAM TEXT IN TOLANG MAUR'S COMMUNITY PERSPECTIVE}

No matter how good a teaching is if it is accepted and interpreted wrongly, then what is wrong is not the teaching. However, people who interpret it wrong. Another analogy that was conveyed by Ustad 'a million people', Zainuddin M.Z. is when you measure wood, is it wood that goes with the meter or the meter that goes with the wood. The wood should follow the meter. If the meter goes with the wood, if the wood is too short, the meter is cut.

Related to this, the Nolam Kanak-Kanak text contains good values that are very appropriate to be conveyed to the community, especially for the family of the deceased child. However, according to Yunus from the results of his research in the three regions of Agam, Pariaman, and Pesisir Selatan the text of Nolam Kanak-Kanak is misinterpreted. The people there consider that the death of a child at an early age is a guarantee for parents to enter heaven. The error is more visible when there are parents who pray for their children to die at an early age. With the hope that the parents will get the intercession of the child who died.

However, this is not the case for the Talang Maur community. From the results of interviews with local people, it was stated that the death of children before puberty was indeed believed to be a wasilah for their parents to enter heaven. However, it is not understood that easily for them. They understand that if the test of death can be accepted with sincerity and patience, then heaven will be the reward.

Such understanding of the Talang Maur community cannot be separated from the role of the ulama in the area. According to Datuk Bijo, who is also a preacher in Talang Maur, he stated that every wirid recitation in our surau (ustad) always reminds the public regarding issues of aqidah, the last days, heaven and hell and their application in life. As far as he knows, there is nothing to worry about people's understanding of the Nolam Kanak-Kanak text.

\section{CONCLUSION}

Nolam Kanak-Kanak is a poem that is sung especially at the time of the death of a child at an early age or before puberty. The way of conveying and in terms of the form of the text, the Nolam Kanak-Kanak tradition is seen as a work of art. This tradition can be spoken by men or women. Usually the Nolam KanakKanak tradition is delivered at night after the tahlilan or yasinan event.

As a text, Nolam Kanak-Kanak contains good values that really deserve to be passed on to the next generation. Among the values of goodness are summarized in patience and sincerity which must be 
the life guidelines for every human being. The community's perspective on the Nolam Kanak-Kanak tradition is good. There is no visible error in the community's understanding of the concept of child death. This straightening of understanding is a sign of the strong role of the ulama in instilling religious issues in the community.

\section{ACKNOWLEDGMENTS}

Our Acknowledgments go to Datuk Bijo, the speaker of the nolam tradition, Mr. Jorong Talang, Buya Fatah and the entire Talang Maur community who have helped us in this research.

\section{REFERENCES}

[1] J. Vansina, Tradisi Lisan sebagai Sejarah. Yogyakarta: Ombak, 2014

[2] Tim Penyusun Kamus Besar Bahasa Indonesia. Kamus Besar Bahasa Indonesia. Jakarta: PT Gramedia Pustaka Utama, 2008

[3] D. Nasri \& F. Dewi. Fungsi dan Makna Teks Nolam dalam Manuskrip Minangkabau di Kabupaten Lima Puluh Kota. Jakarta: Badan Pengembangan dan Pembinaan Bahasa (Laporan Penelitian), 2021

[4] D. Nasri \& F. Dewi. Penelitian Pemetaan Sastra di Kabupaten Lima Puluh Kota. Jakarta: Badan Pengembangan dan Pembinaan Bahasa (Laporan Penelitian), 2021

[5] Y. Yunus, Protes Sastra terhadap Paham Keagamaan: Kajian Nazam Kanak Kanak. Padang: IAIN-IB Press, 2001

[6] Yusriwal, Tabloid Bonsu, Minggu II/9-15 Mei 2001 dan Tabloid Bonsu, Minggu IV/22-29 Mei 2001
[7] M. T. Pamoentjak, Kamoes Bahasa Minangkabau-Bahasa Melajoe-Riau. Batavia: Balai Poestaka, 1935

[8] Y. S. Putra, Humanisme Teosentris dalam sastra Islam Minangkabau: Kajian atas Nazam-Nazam Minangkabau, Yogyakarta: Fakultas Ilmu Budaya, Universitas Gadjah Mada, 2015

[9] S. Endraswara, Metodologi Penelitian Folklor: Konsep, Teori, dan Aplikasi. Yogyakarta: Media Presindo, 2009

[10] S. Y. Sudikan, Metdoe Penelitian Sastra Lisan: Paradigma, Pendekatan, Teori, Konsep, Teknik Penyusunan Proposal, Teknik Pengumpulan Data, Tenik Analisis Data, dan Teknik Penulisan Laporan. Lamongan. Pustaka Ilalang Group, 2015

[11] Sudarmoko (Editor). Direktori Sastra Lisan di Sumatera Barat. Padang: Ruang Kerja Budaya, 2020

[12] M. S. Hakim, 2019. "Hukum Meratapi Mayit". https://muslim.or.id/50884-hukum-meratapimayit.html. diunduh 13 September 2021.

[13] R. Wellek \& A. Warren. Teori Kesusastraan (terjemahan Melani Budianta). Jakarta: Gramedia Pustaka Utama, 1995

[14] Kristina, 6 Kedudukan Anak dalam Islam". Sumber https://news.detik.com/berita/d5619327/6-kedudukan-anak-dalam-islam. diunduh 15 Desember 2021.

[15] Al-Quranulkarim: Al Quran Hafalan (Juz 130). Bandung: Cordoba, 2020

[16] I. Musyarof, Rahasia Sifat Iklas. Yogyakarta: Tugu, 2008 